\title{
The application of the Vona du Toit Model of Creative Ability to self-employment in South African informal microenterprises
}

\author{
* Luther L. Monareng, BSc (Wits); PGD in Hand Therapy (UP); MSc (Wits). \\ https://orcid.org/0000-000I-6780-2436 \\ Lecturer, Department of Occupational Therapy, Faculty of Health Sciences, School of Therapeutic Sciences, University of the \\ Witwatersrand, Johannesburg, South Africa.
}

\section{Denise Franzsen, BSc OT (Wits); MSc OT (Wits); DHT (UP); PhD (Wits). https://orcid.org/0000-000 I-8295-6329 \\ Sessional senior lecturer, Department of Occupational Therapy, Faculty of Health Sciences, School of Therapeutic Sciences, University of the Witwatersrand, Johannesburg, South Africa.}

\section{Daleen Casteleijn, B. Occ. Ther (UP); PGD Voc Rehab (UP); M. Occ. Ther. (Hons)(Medunsa); DHETP (UP); M. Occ Ther (UP); PhD (UP). https://orcid.org/0000-0002-06 I I-8662 \\ Associate Professor, Department of Occupational Therapy, Faculty of Health Sciences, School of Therapeutic Sciences, University of the Witwatersrand, Johannesburg, South Africa.}

\author{
Hester M. van Biljon, B. Occ. Ther. (UFS); M. Occ. Ther. (UFS); PhD (Wits). \\ https://orcid.org/0000-0003-4433-6457 \\ Private practitioner, Work-Link Vocational Rehabilitation Private Practice, Gauteng, South Africa.
}

Introduction: Persons with disabilities experience difficulties entering the formal South African labour market despite progressive legislation to enhance their economic participation. Consequently, self-employment becomes a work placement consideration for occupational therapy clients. However, self-employment requires certain volitional attributes, and the identification of such attributes would greatly enhance the outcome of vocational rehabilitation efforts. The aim of the study was to describe the level of creative ability of self-employed business owners in informal microenterprises.

Method: A descriptive, quantitative non-experimental research design was used. Sixteen self-employed business owners of informal microenterprises were interviewed and observed completing work tasks using the eight domains of the Activity Participation Outcome Measure (APOM) based on the Vona du Toit Model of Creative Ability (VdTMoCA).

Results: Participants were between 27 and 50 years of age. Their education levels ranged from no-education (6\%) to tertiary education (19\%) with the majority (38\%) having a high school education. Based on the APOM scores, participants functioned on three levels of creative ability namely: Passive Participation, Imitative Participation and Active Participation. Most participants functioned at the Imitative patient-directed level with the highest APOM domain scores for all participants being Communication Skills, Affect and Role Performance.

Conclusion: To be successfully self-employed in an informal microenterprise, the required level of creative ability ranging from Passive to Active Participation, was identified. This provides occupational therapists with an understanding of these requirements when considering self-employment as work placement option.

Key words: Self-employment, informal, microenterprise, Vona du Toit Model of Creative Ability (VdTMoCA), Activity Participation Outcome Measure (APOM), work, vocational rehabilitation, placement.

\section{INTRODUCTION AND LITERATURE REVIEW}

South Africa has progressive legislation that protects and promotes the right of persons with disability (PWDs) to enter, return and/ or remain employed in the formal open labour market. However, 25 years after the promulgation of this law, PWDs are still underrepresented in the work force' for a variety of reasons ${ }^{2}$. South Africa's unemployment statistics have reached the all-time high of $32.6 \%$ owing to the COVID-19 pandemic ${ }^{3-5}$, The Commission of Employment Equity (CEE)' reports that PWDs make up $1 \%$ of the workforce in the open labour market. Other than the personal and socio-economic implications this holds for PWDs, it also reflects poorly on the country's compliance with not only the Employment Equity Act $^{6}$ but also the United Nations Sustainable Development Goals (SDGs) ${ }^{7}$ to which South Africa is a signatory. Goal 8 of the SDGs aims to promote sustained, inclusive, and sustainable economic growth, full and productive employment, and decent work for all, including for PWDs.

Occupational therapists have a well-defined role in facilitating clients' engagement in the occupation of work $^{8}$. This role takes into account both the assessment of both the clients' work abil- 
ity and work place when providing vocational rehabilitation and includes preparing a client for seeking, procuring and/or sustaining employment ${ }^{9}$. Both local and global literature shows that the vocational rehabilitation services currently offered by occupational therapists focus mainly on paid employment, with little research and focus on facilitating self-employment or entrepreneurship as a work placement opportunity for their clients ${ }^{10,11}$. Occupational therapy vocational rehabilitation services are currently not in line with the South African government's call for citizens to explore self-employment as an alternative in the face of the high level of unemployment and its effects ${ }^{12}$. Although South African occupational therapists perceive themselves as having a role to play in facilitating self-employment for PWDs, they report a lack of experience in fulfilling this role ${ }^{13}$.

Although there is no consensus on the definition of selfemployment ${ }^{14}$, in this study a self-employed individual in the informal sector is defined as an individual who is working for themselves, being directly or indirectly involved in running a successful and profitable small business or microenterprise in order to earn an income or generate a salary, instead of being employed by another person or an employer. A microenterprise may include, but is not limited to, buying and selling, offering services and manufacturing products on a micro scale ${ }^{14}$. An International Labour Organization (ILO) report of 2019 shows that small businesses and self-employment provide the most jobs worldwide $^{15}$. The informal sector has been prioritised in this study as $61 \%$ of the self-employed work force in the world falls within this sector ${ }^{7}$. To assist PWDs in exploring self-employment as a possible work opportunity or placement and in setting up and successfully running a business, occupational therapists need to understand the factors associated with self-employment to best guide their clients. Therapists need to be aware of the nature of existing knowledge and training the client has, to provide them with the support and guidance they need for successful self-employment. Furthermore, when considering this form of employment as an option in this sector, a clients' ability, level of activity participation, level of education and vocational skills need to be considered ${ }^{16,17}$.

Du Toit postulated that motivation governs action ${ }^{18}$, which is a foundational principle of the Vona du Toit Model of Creative Ability (VdTMoCA) ${ }^{19}$. The VdTMoCA , an occupational therapy practice model that originated in South Africa ${ }^{18}$ is widely used in vocational rehabilitation by South African occupational therapists ${ }^{10}$. This model helps establish an individual's level of creative ability, which guides the occupational therapist in their expectations of a client's performance in the work place ${ }^{18}$.

The Activity Participation Outcome Measure (APOM) based on the VdTMoCA, was used in this study to establish the ability to meet the demands that self-employment places on an individual in microenterprises in the informal sector. The APOM provided a description of the self-employed individual's activity participation profile which forms the basis for deciding whether an individual has a skill at a level that would allow them to run a particular type of business. Since activity participation in the APOM ${ }^{20}$ is based on the levels of creative ability as developed by Vona du Toit, the outcome measure provides occupational therapists with information on the level of motivation and action required to successfully engage in self-employment in a microenterprise in the informal sector.

This study explored self-employment of able-bodied individuals in informal microenterprises in a low resourced urban setting, to provide occupational therapists with a benchmark of the level of activity participation required before exploring self-employment as a work option for their clients.

\section{METHODS}

This study used a quantitative, non-experimental, cross sectional design, where convenience and snowball sampling ${ }^{21}$ was used to locate the business owners. The setting of the study was the low resourced Alexandra Township in Johannesburg. A sample size of 16 self-employed individuals from 46 microenterprises operating in one street (Eighth Avenue), was determined as the required sample according to Cochran's sample size formula with a $5 \%$ margin of error ${ }^{22}$. Eighth Avenue was selected to conduct this study as it represented a typical street of Alexandra Township. Microenterprise owners were selected for participation based on the following inclusion criteria: residents or/and their businesses were located in Alexandra Township; were between the ages of 18 and 65 years; and had been operating or running the business for $\geq$ three years $^{23}$. Their monthly income had to be greater than the monthly South African disability grant amount of RI 600 in $2020^{24}$.

The research instrument used for this study was a questionnaire which recorded demographic data (I5 questions) and the APOM scores. The psychometric properties (validity and reliability) of the APOM have been assessed using Rasch analysis ${ }^{25}$.

Individuals who met the inclusion criteria were visited at their place of business and invited to participate. Appointments were made with each participant to collect the data at a time that was convenient to them. Data for this study were collected by two researchers. Each researcher interviewed each participant and completed the questionnaire specifically designed for this study. Each researcher then observed each participant operating their business for one to two hours and then completed the APOM tool based on their observations. The interview to complete the questionnaire was done first followed by completion of the APOM. The researcher also watched the participant complete their work tasks in their business for e.g., setting up for the day, interacting and/or communicating with customers.

Following the data collection phase, the researchers convened to share, discuss and concur on their findings and scores for purposes of interrater reliability i.e. APOM ratings were discussed and justified with regular reference to the APOM guidelines. The APOM scores were recorded on a spreadsheet and spider graph ${ }^{20}$ were then generated from the data.

Data were analysed descriptively using frequencies and percentages. Demographic data of the participants and type of businesses were presented in frequency tables. APOM results (level of creative ability of the participant), type of business and category of business were described in a table. Median scores for the APOM domains were used to show the level of creative ability for each phase in each level of creative ability. Interpretation of the APOM scores are as follows: scores of $\mathrm{I}-3$ presents the level of Tone, $4-6$ the level of Self-differentiation, 7 - 9 level of Self-presentation, 10 - 12 level of Passive Participation, 13 - 15 level of Imitative Participation and 16 - 18 level of Active Participation. The phases are represented by the specific score within the level e.g. a score of 13 indicates the therapist-directed phase within the level of Imitative Participation, a score of $I 4$ is the person (patient)-directed phase while $I 5$ points to the transitional phase of Imitative Participation ${ }^{20}$.

Ethical clearance (MI 70820) was obtained for this study from theUniversity of the Witwatersrand Health Science Research 

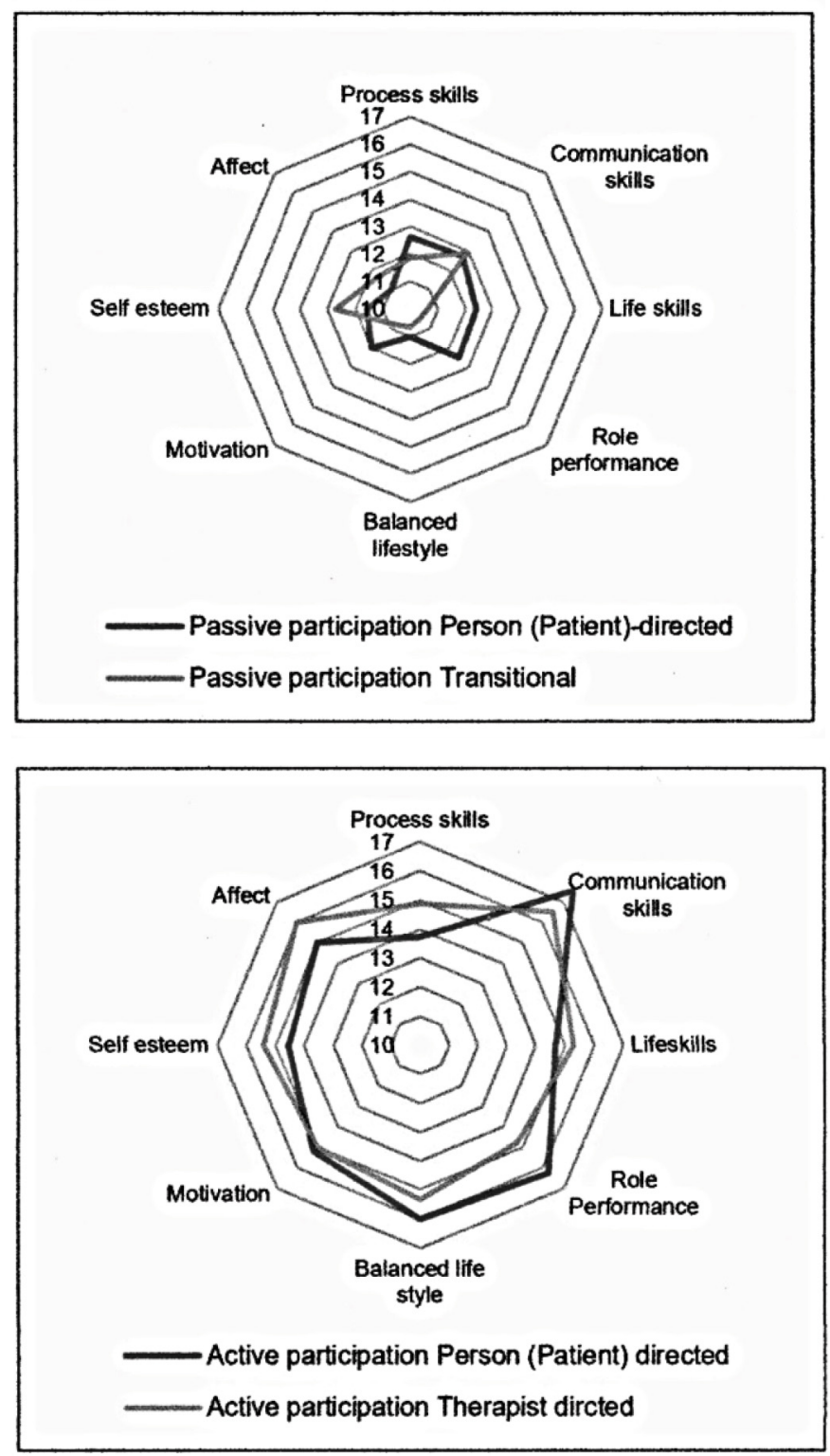

Figure I: Median scores for each domain at each phase in the different levels of creative ability for the participants.

Committee.* During the data collection phase, the purpose of the study and the role of participants in the study were explained using the approved information sheet. Those who agreed to participate signed an informed consent form prior to the data collection. It was explained to participants that their participation in the study was voluntary and they could withdraw without consequence at any time and that the data collected were confidential. To ensure anonymity and confidentiality data collected were coded, no names were captured on any data collection sheets and all docu-ments were kept in secure storage.

\section{RESULTS}

Table I (above) summarises the demographics of the 16 participants. Participants were mostly males, their ages ranged between 27 and 50 years and just over half (56\%) of them

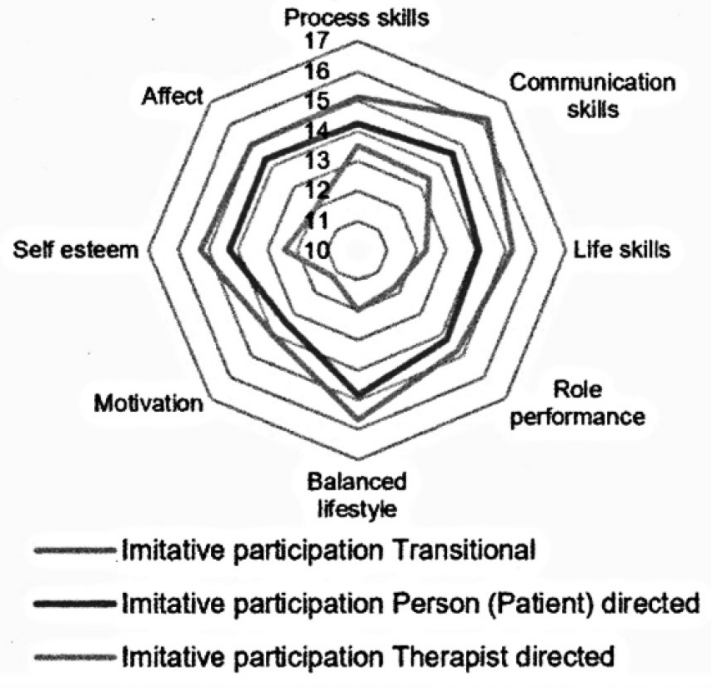

Table I: Demographic profiles of participants

\begin{tabular}{|c|c|c|c|}
\hline & & $\mathrm{n}$ & $\%$ \\
\hline \multirow{2}{*}{ Gender } & Male & 13 & $81 \%$ \\
\hline & Female & 3 & $19 \%$ \\
\hline \multirow{3}{*}{ Age } & $25-35$ years & 5 & $31 \%$ \\
\hline & $36-45$ years & 8 & $50 \%$ \\
\hline & $46-50$ years & 3 & $19 \%$ \\
\hline \multirow{3}{*}{ Marital status } & Married & 7 & $44 \%$ \\
\hline & Single & 7 & $44 \%$ \\
\hline & Cohabitating & 2 & $13 \%$ \\
\hline \multirow{5}{*}{$\begin{array}{l}\text { Level of } \\
\text { education }\end{array}$} & No education & I & $6 \%$ \\
\hline & Primary School & 3 & $19 \%$ \\
\hline & High School (less than Grade I2) & 6 & $36 \%$ \\
\hline & Grade 12 & 3 & $19 \%$ \\
\hline & Tertiary & 3 & $19 \%$ \\
\hline \multirow{3}{*}{$\begin{array}{l}\text { Category of } \\
\text { business }\end{array}$} & Retail & 5 & $31 \%$ \\
\hline & Skills \& services & 8 & $50 \%$ \\
\hline & Manufacturing & 3 & $19 \%$ \\
\hline
\end{tabular}

were either married or co-habiting.

Participants had different levels of creative ability (VdTMoCA). Most businesses were in the retail and service and skills sector (Table II, p77). The type of microenterprises were service and skill, retail and manufacturing/production businesses ${ }^{13}$ such as a privately owned pre-school crèche, a spaza shop and a salon operating from a one-roomed brick house.

\section{Activity Participation}

The highest level of VdTMoCA observed was Active Participation for two (12.5\%) of the business owners. Twelve (75\%) were at the Imitative Participation level and two (12.5\%) at Passive Participation.

Figure I (above) indicates the median scores for each domain at each phase within the different levels of creative ability for the participants. The median of the APOM domain scores indicate 
Table II: Type and category of business according to the participant's level of creative ability (VdTMoCA)

\begin{tabular}{|c|c|c|}
\hline $\begin{array}{l}\text { Level of } \\
\text { Creative ability }\end{array}$ & Type of businesses & $\begin{array}{l}\text { Category of } \\
\text { business }\end{array}$ \\
\hline $\begin{array}{l}\text { Active } \\
\text { Participation } \\
\text { Person (Patient) } \\
\text { directed } \\
(n=1)\end{array}$ & $\begin{array}{l}\text { Printing shop and basic computer training: The shop is a brick structure with signage outside indicating } \\
\text { services that are offered, with basic resources such as printers and computers. It is fairly spacious } \\
\text { inside and one of five other shops located at a multi-purpose centre building. }\end{array}$ & Service/skill \\
\hline $\begin{array}{l}\text { Active } \\
\text { Participation } \\
\text { Therapist } \\
\text { directed }(n=1)\end{array}$ & $\begin{array}{l}\text { Carpentry (Manufacturing, maintenance and repairs e.g. cupboards): No shelter and he works outside his } \\
\text { yard with basic tools such as a cutting machine. Some end-products are left outside while others are } \\
\text { stored in the less spacious room he sleeps in. }\end{array}$ & $\begin{array}{l}\text { Manufacturing/ } \\
\text { production }\end{array}$ \\
\hline $\begin{array}{l}\text { Imitative } \\
\text { Participation } \\
\text { Transitional }(n=3)\end{array}$ & $\begin{array}{l}\text { Spaza shop (Sells e.g. snacks, sweets, cigarettes and cooking ingredients): Operates from a one fairly } \\
\text { spacious room. The shop is a brick structure and located in a yard with the back (selling point) opening } \\
\text { onto the pavement.. There is bold writing and drawings on the wall advertising the products being } \\
\text { sold. The products inside are organised in isles to resemble a formal retail store. } \\
\text { Tailoring (mend torn clothes): The business is located on the pavement outside a multi-purpose centre, } \\
\text { and an umbrella is used as a shelter. He has basic tools such a sewing machine and a stand that is } \\
\text { levelled with a brick since the pavement surface is uneven. His equipment and tools are stored at a } \\
\text { nearby shop. } \\
\text { Restaurant and part time catering to events: The shop is a brick structure, it is fairly spacious and } \\
\text { equipped with basic resources such as gas and electricity stoves and two dining tables. It is one of five } \\
\text { other shops in a multi-purpose centre building. }\end{array}$ & $\begin{array}{l}\text { Service/skill, } \\
\text { retail }\end{array}$ \\
\hline $\begin{array}{l}\text { Imitative } \\
\text { Participation } \\
\text { Person (Patient) } \\
\text { directed }(n=6)\end{array}$ & $\begin{array}{l}\text { Shoe (repairing and manufacturing occasionally): The shelter is made from an old gazebo material which } \\
\text { is secured by ropes on a corner of a shack and a brick wall. A board supported on a crate makes up } \\
\text { his stall which is where he places the shoes due for repairs. He has basic tools such as a sharp nail and } \\
\text { glue. Unfinished products and his tools are stored at a nearby shop. } \\
\text { Creche and after care services: The building is made from bricks and is fairly spacious, windows are } \\
\text { painted with solid primary colours, and the yard is fully fenced which supports a sign by the gate } \\
\text { advertising services being offered. There are basic tools such as kids' tables, chairs and toys. } \\
\text { Second-hand tyres (selling \& fitting): The business is located on the pavement outside a yard and tyres } \\
\text { are displayed in multiple stacks. During the day, he rests under a shelter made from old gazebo } \\
\text { material which is secured on a wall, a brick, a pile of tyres and a piece of steel rod. He has basic tools } \\
\text { such as a tyre lever and an electric air pump. Tyres are assessed for air leakage by placing them in a } \\
\text { half-cut steel drum filled with water. } \\
\text { Hair salons I (plaiting and cutting hair): The one room is a brick structure which is located on the } \\
\text { pavement with signage outside regarding services offered. There are basic tools and material such as } \\
\text { stand-alone hair dryers, towels and mirrors on the wall. The room is fairly spacious inside but not well } \\
\text { organised. } \\
\text { Hair salons } 2 \text { (plaiting, washing and cutting hair): The building is a single-room brick structure, has } \\
\text { limited space and it is located on the pavement with signage outside advertising services offered. There } \\
\text { are basic tools and material such as handheld hair dryers, towels and hair clippers. } \\
\text { Minibus or taxi services: Manages a family business with ten taxis, each with its own driver. At night, } \\
\text { all vehicles are parked in a yard with limited space. The drivers collect the taxis from his yard each } \\
\text { morning to transport passengers locally and to the Johannesburg Central Business District (CBD). }\end{array}$ & $\begin{array}{l}\text { Manufacturing/ } \\
\text { production, } \\
\text { service/skill, retail }\end{array}$ \\
\hline $\begin{array}{l}\text { Imitative } \\
\text { Participation } \\
\text { Therapist } \\
\text { directed }(n=3)\end{array}$ & $\begin{array}{l}\text { Fruits and vegetables (additional items such as cold drinks and snacks): Operated from a brick structure, } \\
\text { located on the pavement and it is fairly spacious. The extended metal tile roof provides shade for the } \\
\text { products. The outside display stall displays goods on sale by hanging all products from the extended } \\
\text { roof (e.g. packets of snacks and packaged onions in plastic bags), a table made from an old wooden } \\
\text { board balanced on empty soft drink crates and a mobile stand or a stall made from steel rods. } \\
\text { Hawker (Snacks, sweets, cigarettes and fruits): The business is operated outside a multi-purpose centre } \\
\text { under a tree, on a pavement and a wheelbarrow is used to transport stock to and from the business } \\
\text { site. The stall is made from an old wooden board balanced on a combination of bricks and old empty } \\
\text { bread crates. A brick and a cushion are used as a chair. } \\
\text { Carpentry (Manufacturing, maintenance and repairs e.g. kitchens units): The building is a brick structure } \\
\text { with a metal garage door at his government provided flat where he works and stores his equipment, } \\
\text { tools and materials. }\end{array}$ & $\begin{array}{l}\text { Manufacturing/ } \\
\text { production, } \\
\text { service/skill, retail }\end{array}$ \\
\hline $\begin{array}{l}\text { Passive } \\
\text { Participation } \\
\text { Transitional }(n=1)\end{array}$ & $\begin{array}{l}\text { Car wash: The shelter has awnings and the floor is paved and spacious. There are basic car wash tools } \\
\text { and materials such as buckets of water, soap and a vacuum cleaner. He has } 3 \text { other people that help } \\
\text { him and he assumes a supervisory role. }\end{array}$ & Service/skill \\
\hline $\begin{array}{l}\text { Passive } \\
\text { Participation } \\
\text { Person (Patient) } \\
\text { directed }(n=1)\end{array}$ & $\begin{array}{l}\text { Car exhaust welding: There is no shelter, the owner works next to the pavement in an open area. } \mathrm{He} \\
\text { has basic tools such as an oxygen tank and welding glasses. }\end{array}$ & Service/skill \\
\hline
\end{tabular}




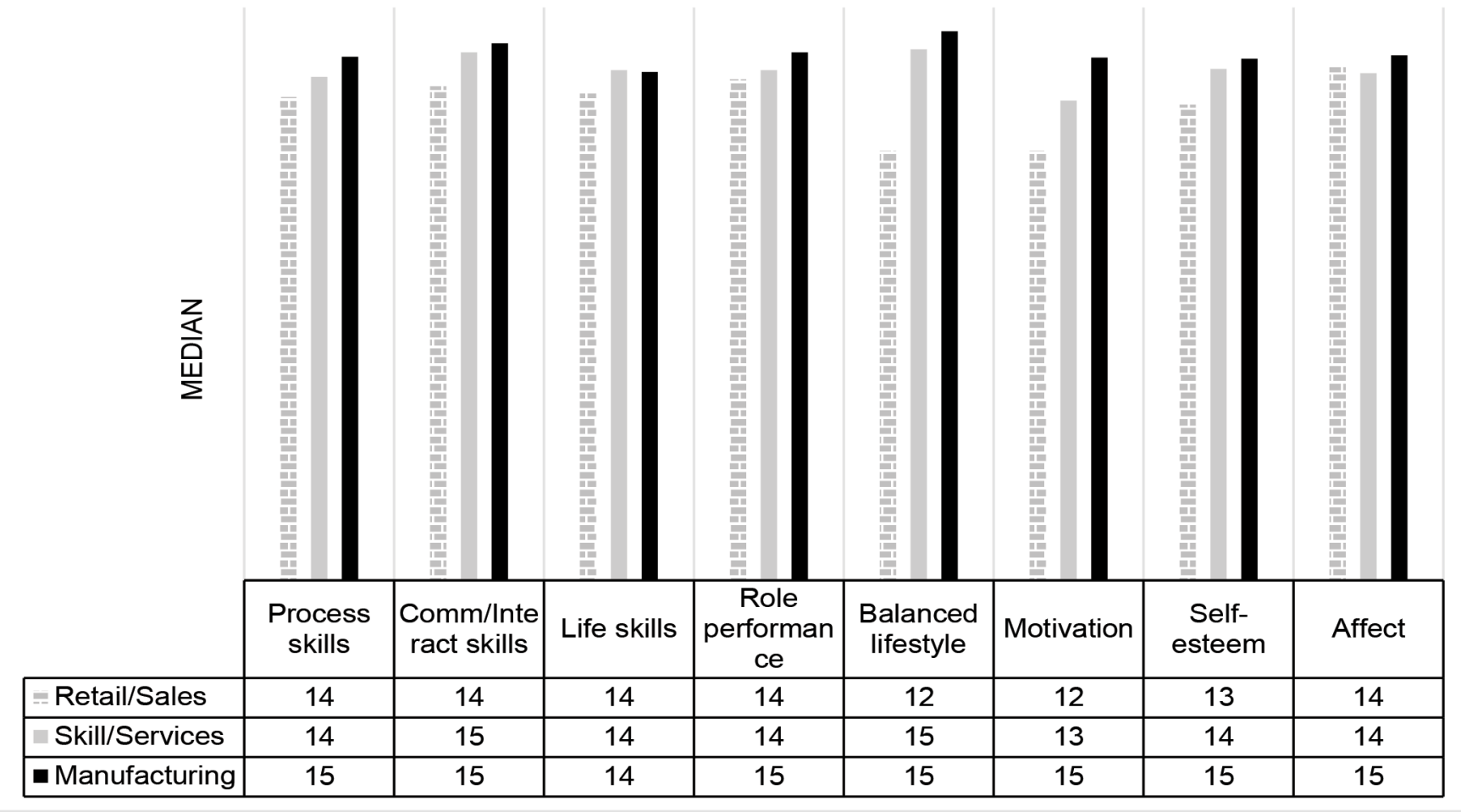

Figure 2: APOM median scores across all business categories.

that all participants scored at or above the Imitative Participation level, person (patient) directed phase $(<\mid 4)$ for the domain of Communication Skills. Motivation domain had the lowest median score with participants on Imitative Participation (I I- I4) and Active Participation ( I5) having Motivation scores which were lower than expected for their level of creative ability. In other domains the scores varied according to the level of creative ability. The participants on Active Participation had lower than expected median scores for Process Skills (14-15) while participants on Imitative Participation person (patient) directed and transitional phase) had higher than expected scores for Self-Esteem (I5-16) and Balanced Lifestyle (15-16).

The APOM median scores across business categories indicated that the highest scores were in "manufacturing" followed by the "services" and "skills" category. The lowest scores were found in the "retail" category across all domains except for the domain of Affect (Figure 2, above).

\section{DISCUSSION}

The demographics of the participants in this study are similar to those reported in the literature for self-employment in low resourced communities in South Africa, with the majority being males between $36-45$ years and with 12 years of formal education ${ }^{22}$. When compared to those participants functioning at lower levels of creative ability (e.g., the Passive Participation level), those functioning at a higher level of creative ability (e.g., the Active Participation level), demonstrated better systems or more effective ways when running their business.

Two of 16 participants were on the Passive Participation level of creative ability of VdTMoCA and they were running businesses in the "service" and "skills" categories. Individuals functioning at this level have difficulty sustaining effort over time and they give up easily if they do not receive support or guidance ${ }^{26}$. Furthermore, although their task concept is developed and their pre-vocational skills are still developing, they may lack the ability to adequately evaluate a product (or service delivered) and may not be able to correct product errors or adjust service delivery where necessary ${ }^{18}$. The two participants at this level of creative ability had many years of experience in the service they offered, and the tasks were habituated, concrete and semi-skilled. The questionnaire results showed that these participants lacked the ability to organise, manage time and money, or marketing their business. They were simply waiting on the side of the road for customers, and this affected their income. Thus, when considering selfemployment with individuals functioning at this level of creative ability, they would require guidance, supervision, and structure. With such support their chances to provide an acceptable level of service will improve.

The majority of the participants $(n=12)$ in this study functioned on the Imitative Participation level according to the VdTMoCA. Individuals functioning at this level need less external structure than those on the Passive Participation level, due to their ability to work independently. They have better Balanced Lifestyle skills and are more organized, structured, follow socially appropriate norms, can evaluate their own performance, and with guidance and practice they can problem-solve, manage their stress and budget and manage their finances adequately ${ }^{20}$. In this study these participants all had financial systems in place, budgeting for stock, planning for fluctuating income and paying the rent. At this level a good Self-Esteem can also be expected which supports their self-efficacy, which is needed to succeed in self-employment ${ }^{27}$. Thus, when considering self-employment for 
individuals functioning at this level of creative ability, an acceptable level of service can be expected but business models should be kept simple to ensure success. In this study, they provided retail, services and skills-based businesses most of which were in their own yards (e.g., one room serves as a spaza shop where items are sold through the window) or based on the pavements (e.g., a gazebo is used for shelter).

Only two (12,5\%) participants in this study functioned on the Active Participation level of creative ability. Such individuals transcend the self, are less egocentric, their focus is on other peoples' needs, they are independent and original in their actions with innovative, problem-solving skills and have a wide repertoire of work skills for which they have received specialized training ${ }^{28}$. Due to self-determination and being action orientated, they are able to identify their goals and have successfully developed and marketed their microenterprises. They also had high scores for Balanced Lifestyle indicating they were able to manage their time well ${ }^{20}$, but their lower Motivation and Process Skills may prevent them from moving to a more competitive small business sector ${ }^{27}$. These participants showed originality in their business practices. They had raised funds for buying instead of renting premises to reduce long term costs, had regular special offers for clients, offered backup services and gave discounts to customers in order to increase sales in their business. Such individuals may be suitable for peer support and in assisting others by offering in-service training especially to those interested in starting similar small businesses.

When the median scores of the domains of the APOM were considered in this study, the high scores for Communication Skills (15) followed by the Affect domain score of 14 suggested that participants in this study had good Communication Skills and a stable mood with appropriate emotional expressions which supported the success of their businesses. A good relationship with customers and the community as well as being a people's person was reported to be instrumental in self-employment ${ }^{29}$ for customers to come back and continue to support a business. Customer relations include treating customers well and controlling emotions when dealing with their concerns.

The median score of the Motivation domain (13) was lowest which seems contrary to that suggested by literature ${ }^{30}$, but still within the Imitative Participation level, indicating that participants may not have a strong internal locus of control ${ }^{31}$. The lack of desire and motivation to expand their businesses, to branch out or operate outside the low-resourced community of Alexandra Township could also be linked to the capabilities of the participants to achieve goals in terms of the Process Skills which were also at an Imitative Participation level ${ }^{27}$. This may be affected by the circumstances under which they set up their businesses. Reasons being, due to necessity, as a result of not being able to find formal employment ${ }^{32}$ and reverting to selfemployment (i.e., running their own businesses) not by choice, but related to survivalist and situation-based considerations ${ }^{33}$. Venturing into the unknown may be a challenge for an individual on Imitative Participation and thus expanding their businesses may be too anxiety provoking. These participants could benefit from a mentor who guides them into marketing and perhaps including more services in their business.

\section{CONCLUSIONS}

This study showed that participants with lower levels of creative ability were involved in retail businesses e.g., buying and selling of snacks on the side of the road. This finding can probably be ascribed to the fact that these businesses require less specific vocational skills and retail businesses in this sector are not complex. This also applies to the management aspect of the business which is often lower in those smaller retail enterprises as they require less organisation and completion of fewer tasks and responsibilities to sustain the business. When the product requires innovation (which participants with a higher level of creative ability are able to introduce), both manufacturing and service businesses are more likely to succeed ${ }^{34}$.

By knowing the abilities required by individuals to be successfully self-employed, occupational therapists should select clients with appropriate skills and abilities when suggesting they engage in self-employment. The use of the APOM based on the VdTMoCA proved useful in identifying individual business owners' skills on eight domains which reflected their ability to run a microenterprise. Although individuals at the Passive Participation level according to the VdTMoCA may be involved in self-employment, they will probably need to be supervised on a regular basis. In this study, those functioning at the higher levels of creative ability (Imitative and Active Participation), were able to independently run successful microenterprises with some differences pertaining to for example, business systems. The study provides information on the amount of support and supervision a person (patient) may need to successfully engage in self-employment, as well as the necessary therapeutic intervention and support to facilitate sustainability.

\section{RECOMMENDATIONS}

This research identified several knowledge gaps that need to be addressed to broaden contextually relevant South African evidence of self-employment for PWD in occupational therapy. The perceptions of PWD on self-employment need to be explored as this could also affect the outcome of occupational therapists' interventions. Guidelines or a conceptual framework, based on the VdTMoCA to enable occupational therapists to identify, encourage and support self-employment for PWDs should be developed.

\section{LIMITATIONS OF THIS STUDY}

The small sample of microenterprise owners participating in this study limits generalisation of the findings. Due to the cross-sectional nature of the observations (which included habituated tasks) may not be consistent with each business owner's general performance. A second visit for observational purposes could have been considered and would have enhanced the discussion.

\section{AUTHOR CONTRIBUTIONS:}

The principal author, Luther Monareng, conducted the research and co-wrote the article.

Denise Franzsen and Daleen Casteleijn assisted in the development of this research, co-supervised the study and contributed to writing the article. Hester van Biljon assisted Mr Monareng with data collection and with writing the article.

\section{Acknowledgements}

Thank you to all the following departments and people who made this research possible:

- University of the Witwatersrand's Faculty of Health Sciences. 
- Colleagues in vocational rehabilitation (Dr. Jennie McAdam, Mr. July Masango and Mr. Simon Rabothata) and Prof P. de Witt for assistance with the article.

- University of the Witwatersrand's Faculty of Health Sciences'

- Claude Leon Merit Award Grant and

- Faculty Research Committee individual grant.

\section{REFERENCES}

I. Department of Labour. 18th Commission for Employment Equity: I.Department of Labour. I8th Commission for Employment Equity: Annual Report 2017-2018. Pretoria: 2019.

2. Ndzwayiba N, Ned L. The Complexity of Disability Inclusion in the Workplace: A South African Study. 2017:127-54. doi: https://doi.org/10.1 108/SI479-354720170000010014.

3. International Labour Office. World Employment and Social Outlook: Trends 2019 Geneva: International Labour Office; 2020 [cited 2020 5th May 2020]. Available from: https://www. ilo.org/wcmsp5/groups/public/---dgreports/---dcomm/---publ/ documents/publication/wcms_670542.pdf.

4. Shakespeare T, Mugeere A, Nyariki E, Simbaya J. Success in Africa: People with disabilities share their stories. African Journal of Disability (Online). 2019;8:1-7.

doi: http://dx.doi.org//0.4/02/ajod.v8i0.522.

5. Statistics South Africa. Significant movements into the labour force in the 3rd quarter of 2020 Pretoria South Africa: Statistics South Africa; 2020 [updated 12 November 2020]. Available from: http://www.statssa.gov.za/?p=13758.

6. Republic of South Africa. Employment Equity Act, No. 55. Pretoria: The Government Printer; 1998.

7. United Nations Development Programme. Sustainable Development Goals 20I5. Available from:

https://www.undp.org/content/undp/en/home/sustainabledevelopment-goals.html.

8. American Occupational Therapy Association. Occupational therapy practice framework: Domain and process (3rd ed.). American Journal of Occupational Therapy. 20I4;68.

9. van Biljon HM, Casteljien D, du Toit SH, Soulsby L. Opinions of occupational therapists on the positioning of vocational rehabilitation services in Gauteng Public Healthcare. South African Journal of Occupational Therapy. 2016;46(I):45-52. doi: http://dx.doi.org/10.17159/2310-3833/2017/vol48n3a8

10. Casteleijn $\mathrm{D}$, de Vos $\mathrm{H}$. The model of creative ability in vocational rehabilitation. Work. 2007;29(I):55-6I.

I I. Crepeau EB CE, Schell BAB. Willard \& Spackman's occupational therapy. 10 ed. Philadelphia: Lippincott; 2003.

12. Bendile N. Ramaphosa encourages entrepreneurship among young South Africans. EYEWITNESS NEWS, 2016.

13. Monareng LL, Franzsen D, van Biljon H. A survey of occupational therapists' involvement in facilitating self- employment for people with disabilities. South African Journal of Occupational Therapy. 2018;48(4):52-7.

doi: https://doi.org/10.17159/2310-3833/2017/vol48n3a8.

14. Parker SC. The economics of self-employment and entrepreneurship: Cambridge University Press; 2004.

15. International Labour Organisation. Small Matters: Global evidence on the contribution to employment by the self-employed, micro-enterprises and SMEs. 2019.

16. Junior Achievement Entrepreneurs are made, not born 2006. Available from: https:/www.juniorachievement.org/web/jaindy/ja-in-the-news/-/blogs/are-entrepreneurs-born-or-made-.

17. Alharthi SZ. Entrepreneurs are Not Born nor Made. Research
Journal of Science and IT Management. 20I 3;2(II):27-34.

18. de Witt P. Creative ability: A model for individual and group occupational therapy for clients with psychosocial dysfunction. In: R C, V A, editors. Occupational therapy in psychiatry and mental health. 5th ed. Oxford: Wiley Blackwell; 2014.

19. du Toit V. Patient volition and action in occupational therapy. Patient volition and action in occupational therapy. South Africa: Vona and Marie du Toit Foundation; 1991.

20. Casteleijn JMF. Development of an outcome measure for occupational therapists in mental health care settings. South Africa: University of Pretoria; 2010.

21. Kielhofner G. Research in Occupational Therapy: Methods of Inquiry for Enhancing Practice Waltner P, Fratantoro CA, editors. Philadelphia: F. A. Davis; 2006.

22. Bartlett JE, Kotrlik JW, Higgins CC. Organizational research: Determining appropriate sample size in survey research appropriate sample size in survey research. Information technology, learning, and performance journal. 2001;19(1):43.

23. Pretorius $M$. Defining business decline, failure and turnaround: A content analysis. The Southern African Journal of Entrepreneurship and Small Business Management. 2009;2(1): I-16. doi: https://doi.org//0.4102/sajesbm.v2il.15.

24. South African Social Security Agency (2017) Disability Grant. Available at: http://www.sassa.gov.za/index.php/social-grants/ disability-grant (accessed June 09 2017).

25. Casteleijn D. Using measurement principles to confirm the levels of creative ability as described in the Vona du Toit Model of Creative Ability. South African Journal of Occupational Therapy. 2014;44(I): I4-9.

26. Oosterbeek H, Van Praag M, ljsselstein A. The impact of entrepreneurship education on entrepreneurship skills and motivation. European economic review. 2010;54(3):442-54. doi: https://doi.org/https://doi.org//0.1016/j.euroecorev.2009.08.002.

27. Luthans F, Avey JB, Avolio BJ, Norman SM, Combs GM. Psychological capital development: toward a micro $\square$ intervention. Journal of Organizational Behavior: The International Journal of Industrial, Occupational and Organizational Psychology and Behavior. 2006;27(3):387-93.

doi: https://doi.org/10.1002/job.373.

28. Luca MR, Cazan A-M, Tomulescu D. To be or not to be an entrepreneur. Procedia-Social and Behavioral Sciences. 2012;33:173-7. doi: https://doi.org/https://doi.org/10.1016/j. sbspro.2012.01.106.

29. Chatterjee N, Das N. A study on the impact of key entrepreneurial skills on business success of Indian micro-entrepreneurs: A case of Jharkhand region. Global Business Review. 2016; 17(1):22637. doi: https://doi.org/10.1177/09721509/5610729.

30. Barba-Sánchez V, Atienza-Sahuquillo C. Entrepreneurial motivation and self-employment: evidence from expectancy theory. International Entrepreneurship and Management Journal. 2017; I3(4): 1097- II 5. doi: https://doi.org/ I0.1007/s I I365-0 I7-044 I-z.

3I. Chell E. The entrepreneurial personality: A social construction: Routledge; 2008.

32. Krasniqi BA. Characteristics of self-employment: A refuge from unemployment or road to entrepreneurship. Small Enterprise Research. 20I4;2I(I):33-53. doi: https://doi.org/I0.1080/13215906.2014.1 1082075.

33. Smallbone D, Welter F. Entrepreneurship and small business development in post-socialist economies: Routledge; 2008. 
34. De Mel S, McKenzie D, Woodruff C. Innovative firms or innovative owners? Determinants of innovation in micro, small, and medium enterprises: The World Bank; 2009.

Corresponding Author:

*Luther L. Monareng

Email: leboganglolo@gmail.com 